Asian-Australasian Journal of Food Safety and Security

ISSN 2523-1073 (Print) 2523-2983 (Online)

www.ebupress.com/journal/aajfss

\title{
Article \\ Effects of gamma irradiation on shelf life and quality of Black Bengal goat meat
}

Saddam Hossain Ruman Khan ${ }^{1}$, Md. Salahuddin ${ }^{2}$, Md. Rezwanul Habib ${ }^{2}$, Md. Mostain Billah ${ }^{2}$, Md. Abu Haris Miah $^{2}$, Shajeda Akhter ${ }^{1}$ and Md. Abul Hashem ${ }^{1 *}$

${ }^{1}$ Department of Animal Science, Bangladesh Agricultural University, Mymensingh-2202, Bangladesh

${ }^{2}$ Bangladesh Livestock Research Institute Regional Station, Baghabari, Shahjadpur, Sirajganj-6770, Bangladesh

*Corresponding author: Professor Dr. Md. Abul Hashem, Department of Animal Science, Bangladesh Agricultural University, Mymensingh-2202, Bangladesh. Phone: +88 01721310621; E-mail: hashem_mdabu@yahoo.com

Received: 07 November 2017/Accepted: 20 November 2017/ Published: 21 November 2017

\begin{abstract}
This study was undertaken to assess the effects of gamma irradiation (0, 1.5, 2, 4 kGy) on shelf life and meat quality of Black Bengal goat. About $3 \mathrm{~kg}$ of fresh Black Bengal goat meat samples were taken and divided into four groups like $\mathrm{T}_{1}$ (non-irradiated, control), $\mathrm{T}_{2}$ (irradiated, $1.5 \mathrm{KGy}$ ), $\mathrm{T}_{3}$ (irradiated, $2.0 \mathrm{KGy}$ ) and $\mathrm{T}_{4}$ (irradiated, $4.0 \mathrm{KGy}$ ). Irradiated and non-irradiated meat samples were stored at refrigeration temperature to elucidate the storage effect. One way ANOVA was performed to investigate the effects of gamma irradiation on different groups. Significant differences were found in color and overall acceptability compared to nonirradiated group and only overall acceptability significantly decreased with increasing storage. No significant differences were observed in flavor, tenderness and juiciness between non-irradiated and irradiated groups. Irradiation influenced color and overall acceptability of chevon. Dry matter content was found higher in 4 KGy irradiated group and increased gradually in day intervals. Cooking loss, free fatty acid, peroxide value and thiobarbituric acid-reactive substances indicated $1.5 \mathrm{KGy}$ irradiation rated best. Microbial findings revealed that 2 KGy irradiated group is better due to safe level of microbial loads which increase shelf life of Black Bengal goat meat. Finally, it may be concluded that 1.5 and $2 \mathrm{KGy}$ doses gamma irradiation in Bengal goat meat enhances sensory attributes, physico-chemical and microbial levels found satisfactory.
\end{abstract}

Keywords: chevon; cooking loss; free fatty acid; peroxide value; microbial loads

\section{Introduction}

Black Bengal goats (BBG) are dwarf breed and are known to be famous due to its adaptability, higher disease resistance, fertility, fecundity, early sexual maturity, larger litter size, delicacy of meat and superior skin quality (Husain et al., 1998). Total number of goat in Bangladesh is about 25.77 million (DLS, 2016). It represents $47.44 \%$ of the total livestock populations of Bangladesh (Salahuddin et al., 2017). BBG constitute nearly $90 \%$ of the total goat population of Bangladesh (Husain et al., 1998). Adult male goat weights about 25-30 kg whereas female $20-25 \mathrm{~kg}$.

Meat is defined as the flesh of animals used as food. Goat meat (Chevon) is an important protein source throughout the world especially in developing countries (Biswas et al., 2007). The term 'fresh meat' includes meat from recently processed animals as well as vacuum packed meat or meat packed in controlled atmospheric gases, which has not undergone any treatment other than chilling to ensure preservation. Fresh meat is also highly perishable product due to its biological composition (Zhou et al., 2010). Chevon is also attractive to health conscious consumers due to its lower fat and higher unsaturated fatty acid levels compared to other traditional red meats (Lee et al., 2008). The diverse nutrient composition of meat makes it an ideal environment for the growth and propagation of meat spoilage micro-organisms and common food-borne pathogens. It is 
therefore essential that adequate preservation technologies are applied to maintain its safety and quality (Aymerich et al., 2008).

Radiation processing of meat is recognized as a safe and effective method among the existing technologies for meat preservation (Al-bachir, 2005). Radiation processing of fresh meat extends the shelf-life and protects the consumer against pathogenic bacteria (Al-bachir and Zeinou, 2009). Even though irradiation is a prospective technology, its application causes physico-chemical and biochemical changes which affect the nutritional value and sensory characteristics of irradiated food (Sohn et al., 2009). The advantages of irradiation in controlling microorganisms and improving the shelf-life of different kinds of red meat such as fresh beef (Chen et al., 2007), lamb meat (Kanatt et al., 2007) and camel meat (Al-bachir and Zeinou, 2009) are well known but there is only limited information in the literature on the effect of gamma irradiation on the quality and shelf-life of goat meat (Modi et al., 2008).

Knowledge on BBG meat preservation techniques as well as its safety and quality are of scarce in this country context. Published data on chemical composition, nutritional and sensory attributes of BBG meat is limited and little information is available in irradiated meat. Hence, this study was taken to investigate the effect of gamma irradiation on shelf-life, sensory attributes and physico-chemical properties of BBG meat.

\section{Materials and Methods}

\subsection{Sample preparation and irradiation}

About $3.0 \mathrm{~kg}$ of fresh BBG meat samples were taken and cleaned with fresh water. Then fat was trimmed off using sharp knife. The samples were divided into four groups and meat samples were packed in airtight zip locked bags, labeled with specific radiation dose before irradiation. Each group was exposed to the irradiation dose except control, 1.5, 2.0 and 4.0 KGy at Bangladesh Institute of Nuclear Agriculture. Meat sample was irradiated through Cobalt ${ }^{60}$ GC-5000 (BRIT, India) machine, whose central dose rate was $4.29 \mathrm{KGy} / \mathrm{hr}$. Treatment group was irradiated with 1.5, 2.0 and 4.0 KGy for 22, 40 and $60 \mathrm{~min}$, respectively. Then meat samples were transferred immediately to the Animal Science Laboratory and stored at $-20^{\circ} \mathrm{C}$.

\subsection{Sensory evaluation}

Sensory evaluation was done by a trained 6-member panel. Panelists were selected among department staff and students and trained according to the American Meat Science Association guidelines (AMSA, 1995). The judges evaluated the samples according to Pena et al. (2009). Sensory qualities of the samples were evaluated after thawing of before cook and after cook. Each sample was evaluated by using a 9-point hedonic scale (9=like extremely, $1=$ dislike extremely). Sensory evaluation was accomplished at 0,30 and 60 days at refrigerated storage condition.

\subsection{Proximate composition analysis}

Dry Matter, ether extract, crude protein and ash were analyzed according to (AOAC, 1995). These proximate components were determined in triplicate and the mean value was recorded.

\subsection{Physico-chemical and biochemical parameters analysis}

\subsubsection{Cooking loss}

About 5g samples weighed and wrapped in a heat-stable foil paper. Then meat sample kept in water bath at $80^{\circ} \mathrm{C}$ for $30 \mathrm{~min}$. Cooking loss was determined as described by (Sultana et al., 2008). Cooking loss was calculated using this equation:

Cooking loss $(\%)=\left[\left(\mathrm{w}_{2}-\mathrm{w}_{3}\right) / \mathrm{w}_{2}\right] \times 100$

Where, $\mathrm{w}_{2}=$ meat weight before cooking $(\mathrm{g})$ and $\mathrm{w}_{3}=$ meat weight after cooking $(\mathrm{g})$.

\subsection{2. $\mathrm{pH}$}

Meat $\mathrm{pH}$ value was measured using $\mathrm{pH}$ meter (Hanna, HI 9002) from raw meat sample.

\section{4.3. Free fatty acid $(\%)$}

The free fatty acid value was determined according to Rukunudin et al. (1998). About $5 \mathrm{~g}$ of meat sample was dissolved in $30 \mathrm{~mL}$ chloroform using a homogenizer (IKA T25digital Ultra-Turrax, Germany) at 10,000 rpm for 1 minute. Then sample was filtered under vacuum using filter paper for removing meat particles. About 4-5 drops of $1 \%$, ethanolic phenolphthalein indicator was added to the filtrate. Then solution was titrated with $0.01 \mathrm{~N}$ ethanolic potassium hydroxide solution. 


\subsubsection{Peroxide value (meq/kg)}

Peroxide value (PV) was determined according to Sallam et al. (2004). About $3 \mathrm{~g}$ meat sample was weighed in a $250-\mathrm{mL}$ glass stopper Erlenmeyer flask and heated in a water bath at $60^{\circ} \mathrm{C}$ for 3 min to melt the fat. Then samples were agitated for 3 min with $30 \mathrm{~mL}$ acetic acid-chloroform solution $(3: 2 \mathrm{v} / \mathrm{v})$ for dissolving the fat. The sample was filtered to remove meat particles. Saturated potassium iodide solution $(0.5 \mathrm{ml})$ was added to the filtrate and continues with the addition of starch solution. The titration was allowed to run against a standard solution of sodium thiosulfate.

\subsubsection{Thiobarbituric acids}

Lipid oxidation was assessed in triplicate using the 2-thiobarbituric acid (TBA) method described by Schmedes et al. (1989). BBG meat samples $(5 \mathrm{~g})$ were blended with $25 \mathrm{~mL}$ of $20 \%$ trichloroacetic acid solution $(200 \mathrm{~g} / \mathrm{L}$ of tricholoroacetic acid in $135 \mathrm{~mL} / \mathrm{L}$ phosphoric acid solution) in a homogenizer (IKA) for $30 \mathrm{sec}$. The homogenized sample was filtered with filter paper and $2 \mathrm{~mL}$ of the filtrate was added with $2 \mathrm{~mL}$ of $0.02 \mathrm{M}$ aqueous TBA solution $(3 \mathrm{~g} / \mathrm{L})$ in a test tube. The test tubes were incubated at $100^{\circ} \mathrm{C}$ for $30 \mathrm{~min}$ and cooled with tap water. The absorbance was measured at $532 \mathrm{~nm}$ using a UV-VIS spectrophotometer (UV-1200, Shimadzu, Japan). The TBA value was expressed as mg malonaldehyde per kilogram of sample.

\subsection{Microbial assessment}

Total viable count (TVC), total coliform count (TCC) and total yeast-mould count (TYMC) were measured by using plate count agar (PCA), MacConkey agar (MCA) and potato dextrose agar (PDA), respectively. Each sample was debilitated into previously prepared normal saline and poured onto each plate and incubated at $37^{\circ} \mathrm{C}$ for overnight. Finally counts were presented as mean colony forming unit per gram (log CFU/g).

\subsection{Statistical model and analysis}

The proposed model for the planned experiment was a factorial experiment with two factors A (Treatments) and $\mathrm{B}$ (Days of intervals) is:

$y i j k=\mu+A i+B j+(A B) i j+\varepsilon i j k i=1, \ldots, a ; j=1, \ldots, b ; k=1, \ldots, n$

Where:

yijk = observation $\mathrm{k}$ in level $\mathrm{i}$ of factor $\mathrm{A}$ and level $\mathrm{j}$ of factor B

$\mu=$ the overall mean

$\mathrm{Ai}=$ the effect of level $\mathrm{i}$ of factor $\mathrm{A}$

$\mathrm{Bj}=$ the effect of level $\mathrm{j}$ of factor B

Data were statistically analyzed using SAS Statistical Discovery Software, NC, USA. DMRT test was used to determine the significance of difference among treatments means.

\section{Results and Discussion}

\subsection{Effect of different doses of irradiation on sensory attributes in BBG meat \\ 3.1.1. Color}

Effects of gamma irradiation on meat color are shown in Table 1. It showed that there no significant differences in color level between control and 1.5 KGy irradiated groups but significant changes existed among control, 2 KGy and 4 KGy groups. Higher color level observed in 2 KGy, 4 KGy irradiated groups at 0 day of storage. This color changes in irradiated fresh meat might be the susceptibility of myoglobin molecule, especially the iron, which alters the chemical environment as well as energy input (Brewer, 2004). The metmyoglobinreducing capacity of fresh meat is essential for the meat to retain its capacity to bloom to a red color following its removal from vacuum packages ( $\mathrm{Li}$ et al., 2012). Metmyoglobin is the pigment responsible for the characteristic brown color of meat as it deteriorates during refrigerated storage (Mancini and Hunt, 2005). In a review, Nam and Ahn (2002) suggested that the mechanism of color change in irradiated meat would be similar to that in non-irradiated meat. The results of this study are not similar with the findings of Yim et al. (2016) who found that the color of the irradiated meat was lower than those of the non-irradiated throughout the ageing period. Kundu et al. (2013) also noted that color of irradiated meat decreased with the advancement of storage periods. 
Table 1. Sensory-attributes (mean $\pm \mathrm{SE})$ in irradiated Black Bengal goat meat.

\begin{tabular}{|c|c|c|c|c|c|c|c|c|c|}
\hline \multirow[t]{2}{*}{ Parameters } & \multirow[t]{2}{*}{ DI } & \multicolumn{4}{|c|}{ Treatments } & \multirow{2}{*}{ Mean \pm SE } & \multicolumn{3}{|c|}{ Level of significance } \\
\hline & & $\mathbf{T}_{1}$ & $\mathbf{T}_{2}$ & $T_{3}$ & $\mathbf{T}_{4}$ & & Treat. & DI & T*DI \\
\hline \multirow{5}{*}{ Colour } & 0 & $5.33 \pm 0.33$ & $5.33 \pm 0.33$ & $5.67 \pm 0.33$ & $6.00 \pm 0.00$ & $5.58^{\mathrm{a}} \pm 0.31$ & \multirow{4}{*}{0.0870} & \multirow{4}{*}{0.6580} & \multirow{4}{*}{0.4481} \\
\hline & 30 & $4.33 \pm 0.33$ & $5.33 \pm 0.33$ & $5.67 \pm 0.33$ & $5.33 \pm 0.33$ & $5.17^{\mathrm{a}} \pm 0.33$ & & & \\
\hline & 60 & $5.00 \pm 0.57$ & $5.33 \pm 0.33$ & $5.33 \pm 0.33$ & $5.33 \pm 0.33$ & $5.25^{\mathrm{a}} \pm 0.38$ & & & \\
\hline & Mean & $4.88^{\mathrm{b}} \pm 0.41$ & $5.33^{\mathrm{ab}} \pm 0.33$ & $5.55^{\mathrm{a}} \pm 0.33$ & $5.55^{\mathrm{a}} \pm 0.22$ & & & & \\
\hline & 0 & $5.66 \pm 0.33$ & $5.33 \pm 0.33$ & $5.66 \pm 0.33$ & $5.66 \pm 0.33$ & $5.58^{\mathrm{a}} \pm 0.33$ & \multirow{4}{*}{0.5447} & \multirow{4}{*}{0.9396} & \multirow{4}{*}{0.8171} \\
\hline \multirow{3}{*}{ Flavour } & 30 & $5.33 \pm 0.33$ & $5.66 \pm 0.33$ & $5.33 \pm 0.33$ & $5.66 \pm 0.33$ & $5.50^{\mathrm{a}} \pm 0.33$ & & & \\
\hline & 60 & $5.66 \pm 0.33$ & $5.33 \pm 0.33$ & $5.00 \pm 0.57$ & $6.00 \pm 0.57$ & $5.50^{a} \pm 0.60$ & & & \\
\hline & Mean & $5.55^{\mathrm{a}} \pm 0.33$ & $5.44^{\mathrm{a}} \pm 0.33$ & $5.33^{\mathrm{a}} \pm 0.41$ & $5.77^{a} \pm 0.41$ & & & & \\
\hline \multirow{5}{*}{ Tenderness } & 0 & $5.67 \pm 0.33$ & $5.67 \pm 0.33$ & $5.67 \pm 0.33$ & $6.00 \pm 0.00$ & $5.75^{\mathrm{a}} \pm 0.25$ & \multirow{4}{*}{0.5265} & \multirow{4}{*}{$<.0001$} & \multirow{4}{*}{0.6594} \\
\hline & 30 & $5.67 \pm 0.33$ & $5.00 \pm 0.00$ & $6.00 \pm 0.57$ & $6.00 \pm 0.57$ & $5.66^{a} \pm 0.37$ & & & \\
\hline & 60 & $5.67 \pm 0.33$ & $5.67 \pm 0.33$ & $5.33 \pm 0.33$ & $5.67 \pm 0.33$ & $5.58^{a} \pm 0.33$ & & & \\
\hline & Mean & $5.66^{a} \pm 0.33$ & $5.44^{\mathrm{a}} \pm 0.22$ & $5.66^{\mathrm{a}} \pm 0.38$ & $5.88^{a} \pm 0.26$ & & & & \\
\hline & 0 & $5.66 \pm 0.33$ & $6.67 \pm 0.33$ & $6.00 \pm 0.57$ & $5.66 \pm 0.33$ & $6.00^{\mathrm{a}} \pm 0.39$ & & & \\
\hline \multirow{3}{*}{ Juiciness } & 30 & $6.33 \pm 0.33$ & $5.33 \pm 0.33$ & $5.33 \pm 0.33$ & $5.33 \pm 0.33$ & $5.58^{\mathrm{ab}} \pm 0.33$ & \multirow{3}{*}{0.5950} & \multirow{3}{*}{$<.0001$} & \multirow{3}{*}{0.2206} \\
\hline & 60 & $5.33 \pm 0.33$ & $5.33 \pm 0.33$ & $5.33 \pm 0.33$ & $5.33 \pm 0.33$ & $5.33^{\mathrm{b}} \pm 0.33$ & & & \\
\hline & Mean & $5.78^{\mathrm{a}} \pm 0.33$ & $5.78^{\mathrm{a}} \pm 0.33$ & $5.55^{\mathrm{a}} \pm 0.41$ & $5.44^{\mathrm{a}} \pm 0.33$ & & & & \\
\hline \multirow{4}{*}{$\begin{array}{l}\text { Overall } \\
\text { acceptability }\end{array}$} & 0 & $6.33 \pm 0.33$ & $6.67 \pm 0.33$ & $6.67 \pm 0.33$ & $6.66 \pm 0.33$ & $5.50^{\mathrm{a}} \pm 0.42$ & \multirow{4}{*}{0.1768} & \multirow{4}{*}{0.0004} & \multirow{4}{*}{0.9380} \\
\hline & 30 & $5.33 \pm 0.33$ & $5.67 \pm 0.33$ & $6.33 \pm 0.33$ & $5.67 \pm 0.33$ & $4.87^{\mathrm{b}} \pm 0.36$ & & & \\
\hline & 60 & $5.00 \pm 0.57$ & $5.33 \pm 0.33$ & $5.67 \pm 0.33$ & $5.67 \pm 0.33$ & $4.33^{\mathrm{b}} \pm 0.39$ & & & \\
\hline & Mean & $5.55^{\mathrm{b}} \pm 0.41$ & $5.89^{\mathrm{ab}} \pm 0.33$ & $6.22^{\mathrm{a}} \pm 0.33$ & $6.00^{\mathrm{ab}} \pm 0.33$ & & & & \\
\hline
\end{tabular}

Mean in each row and column having different superscript varies significantly $(\mathrm{p}<0.05)$.

T1, Control; $\mathrm{T}_{2}, 1.5 \mathrm{KGy}$ irradiated; $\mathrm{T}_{3}, 2$ KGy irradiated; $\mathrm{T}_{4}, 4$ KGy irradiated.

DI, Days of Intervals; Treat, Treatment; T*DI, Interaction of Treatment and Days of Intervals.

\subsubsection{Flavor}

Effects of gamma irradiation on meat flavor are shown in Table 1. Results revealed that flavor non-significantly differed between the non-irradiated and irradiated groups but higher flavor score was found in 4 KGy irradiated group. Storage time had no significant $(\mathrm{P}>0.05)$ effects on flavor. This findings is supported by Al-Bachir et al. (2010) who noted that flavor of the chicken kabab product were not influenced by the irradiation treatment. Again, Modi et al. (2008) observed that flavor significantly decreased with advancement of storage which is contradicted with this study.

\subsubsection{Tenderness and juiciness}

Statistically no significant differences were found in tenderness and juiciness between non-irradiated and irradiated groups. There were also non-significant $(\mathrm{P}>0.05)$ changes of tenderness in day's interval but decreased trend observed in juiciness which is similar with (Badar, 2004). Again, this result was not supported by Ali and Zahran (2010) who reported that tenderness of chicken meat improved due to irradiation.

\subsubsection{Overall acceptability}

Effects of gamma irradiation on BBG meat overall acceptability are shown in Table 1. It revealed that significant differences existed in $2 \mathrm{KGy}$ irradiated groups compare to control. Results also showed that overall acceptability was significantly differed in 30 and 60 days compared with 0 day of storage.

\subsection{Effects of different doses of irradiation on proximate composition in goat meat}

\subsubsection{Dry matter $(\%)$}

Effects of gamma irradiation on dry matter (DM) in BBG goat meat are presented in Table 2. Results imply that significant difference existed in dry matter content among irradiated groups and $4 \mathrm{KGy}$ irradiated group showed higher dry matter content than others. Non-significant differences present between control and $\mathrm{T}_{4}$ groups. With the advancement of storage time dry matter increased gradually and higher dry matter was observed in 60 days of storage which is similar to Modi et al. (2008); Konieczny et al. (2007) who reported that dry matter content increased with storage time. The improvement of DM contents in meat probably due to reduction of metabolic activities. 
3.2.2. Crude protein, ether extract and ash (\%)

Crude protein, ether extract and ash percentages are shown in Table 2. Non-significant differences were found in crude protein, ether extract and ash between non-irradiated and irradiated groups. There were also no significant changes present among storage periods of these parameters. This may be due to the fact that the presence of the soluble solids in meat juice may exert a considerable effect in protecting the protein from radiation damage (Batzer et al., 1955). The present findings were supported by Al-Bachir et al. (2010) and Bakalivanova et al. (2009) who reported that no significant differences in the protein of meat were observed due to irradiation as well as increased in oxidation activity and lipid per oxidation both radiation treatment and storage time on meat and meat products. Again, Arannilewa et al. (2005) observed ash content of the meat decreased with frozen storage period.

Table 2. Proximate composition (mean \pm SE) in irradiated Black Bengal goat meat.

\begin{tabular}{|c|c|c|c|c|c|c|c|c|c|}
\hline \multirow{2}{*}{\multicolumn{2}{|c|}{ Parameters DI }} & \multicolumn{4}{|c|}{ Treatments } & \multirow{2}{*}{ Mean \pm SE } & \multicolumn{3}{|c|}{ Level of significance } \\
\hline & & $T_{1}$ & $\mathbf{T}_{2}$ & $T_{3}$ & $\mathbf{T}_{4}$ & & Treat. & DI & T*DI \\
\hline \multirow{4}{*}{$\mathrm{DM}(\%)$} & 0 & $29.39 \pm 0.52$ & $28.21 \pm 0.64$ & $28.16 \pm 0.56$ & $29.80 \pm 0.62$ & $28.89^{\mathrm{b}} \pm 0.59$ & \multirow{4}{*}{0.0468} & \multirow{4}{*}{0.0022} & \multirow{4}{*}{0.8876} \\
\hline & 30 & $29.61 \pm 0.38$ & $28.87 \pm 0.86$ & $28.93 \pm 0.63$ & $29.87 \pm 0.59$ & $29.32^{\mathrm{b}} \pm 0.62$ & & & \\
\hline & 60 & $30.32 \pm 0.51$ & $29.77 \pm 0.69$ & $30.75 \pm 0.65$ & $31.56 \pm 0.31$ & $30.60^{\mathrm{a}} \pm 0.54$ & & & \\
\hline & Mean & $29.77^{\mathrm{ab}} \pm 0.47$ & $28.95^{\mathrm{b}} \pm 0.73$ & $29.28^{\mathrm{b}} \pm 0.59$ & $30.41^{\mathrm{a}} \pm 0.47$ & & & & \\
\hline \multirow{4}{*}{$\mathrm{CP}(\%)$} & 0 & $22.04 \pm 0.35$ & $22.41 \pm 0.50$ & $23.07 \pm 0.39$ & $22.46 \pm 0.75$ & $22.49^{\mathrm{a}} \pm 0.50$ & \multirow{4}{*}{0.6719} & \multirow{4}{*}{0.7522} & \multirow{4}{*}{0.5158} \\
\hline & 30 & $22.45 \pm 0.85$ & $21.10 \pm 0.59$ & $22.45 \pm 0.31$ & $22.79 \pm 0.35$ & $22.20^{\mathrm{a}} \pm 0.53$ & & & \\
\hline & 60 & $22.37 \pm 0.33$ & $22.47 \pm 0.32$ & $22.10 \pm 1.00$ & $22.13 \pm 0.60$ & $22.26^{\mathrm{a}} \pm 0.57$ & & & \\
\hline & Mean & $22.29^{\mathrm{a}} \pm 0.45$ & $21.99^{\mathrm{a}} \pm 0.47$ & $22.54^{\mathrm{a}} \pm 0.57$ & $22.46^{\mathrm{a}} \pm 0.57$ & & & & \\
\hline \multirow{4}{*}{$\mathrm{EE}(\%)$} & 0 & $2.09 \pm 0.60$ & $2.39 \pm 0.27$ & $2.97 \pm 0.58$ & $2.80 \pm 0.34$ & $2.56^{\mathrm{a}} \pm 0.45$ & \multirow{4}{*}{0.8120} & \multirow{4}{*}{0.5450} & \multirow{4}{*}{0.3497} \\
\hline & 30 & $2.94 \pm 0.34$ & $2.53 \pm 0.31$ & $2.78 \pm 0.38$ & $3.33 \pm 0.34$ & $2.89^{\mathrm{a}} \pm 0.34$ & & & \\
\hline & 60 & $2.49 \pm 0.58$ & $3.27 \pm 0.30$ & $2.74 \pm 0.29$ & $2.15 \pm 0.55$ & $2.66^{\mathrm{a}} \pm 0.43$ & & & \\
\hline & Mean & $2.50^{\mathrm{a}} \pm 0.51$ & $2.73^{\mathrm{a}} \pm 0.29$ & $2.83^{\mathrm{a}} \pm 0.41$ & $2.76^{\mathrm{a}} \pm 0.41$ & & & & \\
\hline \multirow{4}{*}{ Ash (\%) } & 0 & $1.35 \pm 0.10$ & $1.36 \pm 0.19$ & $1.17 \pm 0.09$ & $1.21 \pm 0.10$ & $1.27^{\mathrm{a}} \pm 0.12$ & \multirow{4}{*}{0.1597} & \multirow{4}{*}{0.3555} & \multirow{4}{*}{0.9602} \\
\hline & 30 & $1.44 \pm 0.08$ & $1.46 \pm 0.21$ & $1.32 \pm 0.03$ & $1.21 \pm 0.03$ & $1.36^{\mathrm{a}} \pm 0.09$ & & & \\
\hline & 60 & $1.42 \pm 0.12$ & $1.48 \pm 0.09$ & $1.26 \pm 0.06$ & $1.40 \pm 0.06$ & $1.39^{\mathrm{a}} \pm 0.08$ & & & \\
\hline & Mean & $1.40^{\mathrm{a}} \pm 0.10$ & $1.43^{\mathrm{a}} \pm 0.16$ & $1.25^{\mathrm{a}} \pm 0.06$ & $1.27^{\mathrm{a}} \pm 0.06$ & & & & \\
\hline
\end{tabular}

Mean in each row and column having different superscript varies significantly $(\mathrm{p}<0.05)$.

$\mathrm{T}_{1}$, Control; $\mathrm{T}_{2}, 1.5 \mathrm{KGy}$ irradiated; $\mathrm{T}_{3}, 2 \mathrm{KGy}$ irradiated; $\mathrm{T}_{4}, 4$ KGy irradiated.

DI, Days of Intervals; Treat, Treatment; T*DI, Interaction of Treatment and Days of Intervals.

DM, Dry matter; CP, Crude protein; EE, Ether extract.

\subsection{Effects of different doses of irradiation on physico-chemical and biochemical properties in BBG meat} 3.3.1. Cooking loss

Table 3 showed that significant difference existed in cooking loss between non-irradiated and irradiated groups. Non-significant ( $p>0.05)$ changes observed in storage periods but higher cooking loss was found at 30 days at storage. Again, Yoon (2003) stated irradiation significantly increase cooking loss percentage in meat due to damage of muscle fibers and myofibrils as well as denaturation of muscle proteins.

\subsection{2. pH}

Effects of gamma irradiation on $\mathrm{pH}$ are shown in Table 3 and it showed that there was no significant difference present between non-irradiated and irradiated groups. With the increment of storage time $\mathrm{pH}$ had decreased but higher $\mathrm{pH}$ value was observed at 0 day of storage. The lack of change in $\mathrm{pH}$ reflects that there were not enough protein breakdowns during these storage times to elicit increased $\mathrm{pH}$ typical of meat storage for longer periods (Modi et al., 2008). The increase in fat values in irradiated samples and during storage caused a decrease in $\mathrm{pH}$ values (Morales-delanuez et al., 2009) which support this study finding. Similar results also found Aftab et al. (2015) who carried out a research on irradiated broiler chicken meat and found $\mathrm{pH}$ was slightly decreased as the dose increased in refrigerator storage condition.

\subsubsection{Free fatty acid $(\%)$}

Table 3 revealed that non-significant difference existed in FFA $(\%)$ between control and $\mathrm{T}_{2}$ groups as well as $\mathrm{T}_{3}$ and $\mathrm{T}_{4}$ groups. Irradiated group showed higher free fatty acid value compared to control group. An increasing trend of free fatty acid was observed with the advancement of storage periods. Lescano et al. (1991) found 
chicken half breasts packed in polystyrene trays and wrapped with PVC film that is irradiated at a dose of 4.5 KGy showed higher FFA content compared to non-irradiated control samples. Irradiation accelerates the lipid oxidation process which is highly significant in foods with a high content of fats and much unsaturated fatty acids in which numerous free radicals are formed due to this oxidation (O'Bryan et al., 2008).

\subsubsection{Peroxide value (\%)}

Statistically non-significant ( $p>0.05$ ) differences observed in peroxide value among control, 1.5 and 2 KGy irradiated groups. 4 KGy irradiated group showed significantly higher peroxide value than control group. Peroxide value significantly increased with the increment of storage time and higher peroxide value was observed in 60 days of storage. The results of this study agrees with the findings of Al-Bachir and Zeinou (2009) who reported that an increase in oxidation activity and lipid peroxidation due to radiation treatment and storage time.

\subsubsection{Thiobarbituric acid reactive substances (\%)}

Effects of gamma irradiation on thiobarbituric acid reactive substances are shown in Table 3 and it revealed that significant differences present between non-irradiated and irradiated groups. The TBARS increased with the increasing doses of irradiation. Higher TBARS was observed in $4 \mathrm{KGy}$ irradiated group and these results agrees with findings of Kim et al. (2012). Lewis et al. (2002) stated that TBARS value of chicken breast fillets were greater than that of control samples over the storage due to subjection of 1 and $1.8 \mathrm{KGy}$ and further it increased as storage time increased. The present findings not supported by Chun et al. (2010) findings who reported that no significant differences in TBARS values for both increasing irradiation doses and increasing storage period in chicken breasts.

Table 3. Physico-chemical and biochemical properties in irradiated Black Bengal goat meat.

\begin{tabular}{|c|c|c|c|c|c|c|c|c|c|}
\hline \multirow{2}{*}{ Parameters } & \multirow{2}{*}{ DI } & \multicolumn{4}{|c|}{ Treatments } & \multirow{2}{*}{ Mean \pm SE } & \multicolumn{3}{|c|}{ Level of significance } \\
\hline & & $\mathbf{T}_{1}$ & $\mathbf{T}_{2}$ & $\mathbf{T}_{3}$ & $\mathbf{T}_{4}$ & & Treat. & DI & $\mathbf{T} * \mathbf{D I}$ \\
\hline \multirow{4}{*}{$\mathrm{pH}$} & 0 & $6.05 \pm 0.16$ & $6.17 \pm 0.10$ & $6.12 \pm 0.17$ & $5.88 \pm 0.07$ & $6.05^{\mathrm{a}} \pm 0.12$ & \multirow{4}{*}{0.7928} & \multirow{4}{*}{0.0007} & \multirow{4}{*}{0.6374} \\
\hline & 30 & $5.83 \pm 0.16$ & $5.64 \pm 0.17$ & $5.69 \pm 0.11$ & $5.64 \pm 0.07$ & $5.70^{\mathrm{b}} \pm 0.13$ & & & \\
\hline & 60 & $5.45 \pm 0.23$ & $5.73 \pm 0.12$ & $5.61 \pm 0.14$ & $5.67 \pm 0.09$ & $5.61^{\mathrm{b}} \pm 0.14$ & & & \\
\hline & Mean & $5.78^{\mathrm{a}} \pm 0.18$ & $5.85^{\mathrm{a}} \pm 0.13$ & $5.81^{\mathrm{a}} \pm 0.14$ & $5.73^{\mathrm{a}} \pm 0.07$ & & & & \\
\hline \multirow{4}{*}{$\begin{array}{l}\text { Cooking } \\
\text { Loss }(\%)\end{array}$} & 0 & $21.16 \pm 0.53$ & $22.88 \pm 0.22$ & $22.99 \pm 0.34$ & $23.53 \pm 0.37$ & $22.64^{\mathrm{a}} \pm 0.36$ & \multirow{4}{*}{$<0.0001$} & \multirow{4}{*}{0.2165} & \multirow{4}{*}{0.8708} \\
\hline & 30 & $20.82 \pm 0.51$ & $22.70 \pm 0.63$ & $23.54 \pm 0.50$ & $24.06 \pm 0.57$ & $22.78^{\mathrm{a}} \pm 0.55$ & & & \\
\hline & 60 & $19.56 \pm 0.33$ & $22.48 \pm 0.62$ & $22.84 \pm 0.63$ & $23.35 \pm 0.35$ & $22.06^{\mathrm{a}} \pm 0.48$ & & & \\
\hline & Mean & $20.51^{b} \pm 0.46$ & $22.68^{\mathrm{a}} \pm 0.49$ & $23.12^{\mathrm{a}} \pm 0.49$ & $23.64^{\mathrm{a}} \pm 0.43$ & & & & \\
\hline \multirow{4}{*}{ FFA $(\%)$} & 0 & $0.23 \pm 0.03$ & $0.32 \pm 0.03$ & $0.38 \pm 0.01$ & $0.45 \pm 0.01$ & $0.35^{\mathrm{c}} \pm 0.02$ & \multirow{4}{*}{$<.0001$} & \multirow{4}{*}{$<.0001$} & \multirow{4}{*}{$<.0001$} \\
\hline & 30 & $0.66 \pm 0.02$ & $0.71 \pm 0.01$ & $0.77 \pm 0.01$ & $0.63 \pm 0.07$ & $0.69^{\mathrm{b}} \pm 0.03$ & & & \\
\hline & 60 & $0.64 \pm 0.06$ & $0.60 \pm 0.02$ & $1.23 \pm 0.08$ & $1.40 \pm 0.17$ & $0.96^{\mathrm{a}} \pm 0.08$ & & & \\
\hline & Mean & $0.51^{\mathrm{b}} \pm 0.04$ & $0.54^{\mathrm{b}} \pm 0.02$ & $0.79^{\mathrm{a}} \pm 0.03$ & $0.83^{\mathrm{a}} \pm 0.08$ & & & & \\
\hline \multirow{4}{*}{$\begin{array}{l}\text { PV } \\
\text { ( meq/kg) }\end{array}$} & 0 & $1.03 \pm 0.01$ & $0.87 \pm 0.01$ & $0.88 \pm 0.04$ & $1.30 \pm 0.05$ & $1.02^{c} \pm 0.03$ & \multirow{4}{*}{$<.0001$} & \multirow{4}{*}{$<.0001$} & \multirow{4}{*}{$<.0001$} \\
\hline & 30 & $0.82 \pm 0.02$ & $1.04 \pm 0.02$ & $1.23 \pm 0.06$ & $1.37 \pm 0.03$ & $1.12^{\mathrm{b}} \pm 0.04$ & & & \\
\hline & 60 & $1.22 \pm 0.03$ & $1.25 \pm 0.05$ & $0.99 \pm 0.04$ & $1.38 \pm 0.03$ & $1.21^{\mathrm{a}} \pm 0.04$ & & & \\
\hline & Mean & $1.02^{\mathrm{b}} \pm 0.02$ & $1.05^{\mathrm{b}} \pm 0.03$ & $1.04^{\mathrm{b}} \pm 0.05$ & $1.35^{\mathrm{a}} \pm 0.04$ & & & & \\
\hline \multirow{4}{*}{$\begin{array}{l}\text { TBARS } \\
(\mathrm{mg}- \\
\text { MDA/kg) }\end{array}$} & 0 & $0.06 \pm 0.01$ & $0.15 \pm 0.01$ & $0.20 \pm 0.01$ & $0.23 \pm 0.01$ & $0.16^{\mathrm{c}} \pm 0.01$ & \multirow{4}{*}{$<.0001$} & \multirow{4}{*}{$<.0001$} & \multirow{4}{*}{$<.0001$} \\
\hline & 30 & $0.19 \pm 0.01$ & $0.31 \pm 0.01$ & $0.40 \pm 0.01$ & $0.55 \pm 0.01$ & $0.36^{\mathrm{b}} \pm 0.02$ & & & \\
\hline & 60 & $0.21 \pm 0.01$ & $0.46 \pm 0.01$ & $0.76 \pm 0.03$ & $0.58 \pm 0.04$ & $0.50^{\mathrm{a}} \pm 0.02$ & & & \\
\hline & Mean & $0.15^{\mathrm{c}} \pm 0.01$ & $0.31^{\mathrm{b}} \pm 0.01$ & $0.45^{\mathrm{a}} \pm 0.02$ & $0.45^{\mathrm{a}} \pm 0.02$ & & & & \\
\hline
\end{tabular}

Mean in each row and column having different superscript varies significantly $(\mathrm{p}<0.05)$.

$\mathrm{T}_{1}$, Control; $\mathrm{T}_{2}, 1.5 \mathrm{KGy}$ irradiated; $\mathrm{T}_{3}, 2 \mathrm{KGy}$ irradiated; $\mathrm{T}_{4}, 4 \mathrm{KGy}$ irradiated.

DI, Days of Intervals; Treat, Treatment; T*DI, Interaction of Treatment and Days of Intervals.

FFA, Free fatty acid; PV, Peroxide value; TBARS, Thiobarbituric acid reactive substances; DI, Days of Intervals.

\subsection{Effects of different doses of irradiation on microbial loads in Black Bengal goat meat 3.4.1. Total viable counts $(\log \mathrm{CFU} / \mathrm{g})$}

The total viable count of $\mathrm{T}_{1}, \mathrm{~T}_{2}, \mathrm{~T}_{3}$ and $\mathrm{T}_{4}$ type irradiated meats are shown in Table 4 . Research findings showed that there was significant difference among the different meat samples. The highest total viable count was found in meat irradiated with $1.5 \mathrm{KGy}$ and the lowest found in $4.0 \mathrm{KGy}$ irradiated meat samples. TVC showed a 
decreasing trend with the increasing doses of irradiation and TVC increased gradually with the storage periods increased. Similar results also found by Ferawati et al. (2015) of total plate count showed that the microbial loads of the irradiated samples were lower than control and this finding confirms the reduction of the microbial count after irradiation of the fresh meat samples. Food spoilage microorganisms are generally susceptible to irradiation, 90\% reduction of most vegetative cells can be accomplished with 1-1.5 KGy (Brewer, 2004).

Table 4. Effect of different doses of irradiation on microbial population in Black Bengal goat meat.

\begin{tabular}{|c|c|c|c|c|c|c|c|c|c|}
\hline \multirow[t]{2}{*}{ Parameters } & \multirow[t]{2}{*}{ DI } & \multicolumn{4}{|c|}{ Treatments } & \multirow{2}{*}{ Mean \pm SE } & \multicolumn{3}{|c|}{ Level of significance } \\
\hline & & $T_{1}$ & $\mathbf{T}_{2}$ & $\mathbf{T}_{3}$ & $\mathbf{T}_{4}$ & & Treat. & DI & T*DI \\
\hline \multirow{4}{*}{$\begin{array}{l}\text { TVC } \\
(\log \mathrm{CFU} / \mathrm{g})\end{array}$} & 0 & $4.25 \pm 0.10$ & $3.72 \pm 0.02$ & $3.78 \pm 0.09$ & $3.64 \pm 0.05$ & $3.84^{\mathrm{c}} \pm 0.07$ & \multirow{4}{*}{$<.0001$} & \multirow{4}{*}{$<.0001$} & \multirow{4}{*}{$<.0001$} \\
\hline & 30 & $4.68 \pm 0.01$ & $3.81 \pm 0.07$ & $4.02 \pm 0.01$ & $4.03 \pm 0.01$ & $4.13^{b} \pm 0.04$ & & & \\
\hline & 60 & $4.02 \pm 0.01$ & $5.63 \pm 0.03$ & $4.83 \pm 0.08$ & $4.57 \pm 0.04$ & $4.76^{\mathrm{a}} \pm 0.04$ & & & \\
\hline & Mean & $4.32^{\mathrm{a}} \pm 0.04$ & $4.38^{\mathrm{a}} \pm 0.04$ & $4.21^{\mathrm{b}} \pm 0.06$ & $4.08^{c} \pm 0.03$ & & & & \\
\hline TCC & 0 & $1.22 \pm 0.04$ & $1.05 \pm 0.02$ & $0.94 \pm 0.02$ & $1.58 \pm 0.03$ & $1.20^{\mathrm{a}} \pm 0.04$ & \multirow{4}{*}{0.0020} & \multirow{4}{*}{$<.0001$} & \multirow{4}{*}{$<.0001$} \\
\hline \multirow[t]{3}{*}{$(\log \mathrm{CFU} / \mathrm{g})$} & 30 & $1.12 \pm 0.02$ & $1.15 \pm 0.01$ & $0.90 \pm 0.01$ & $0.72 \pm 0.02$ & $0.97^{\mathrm{b}} \pm 0.02$ & & & \\
\hline & 60 & $1.06 \pm 0.01$ & $1.34 \pm 0.02$ & $1.38 \pm 0.06$ & $1.03 \pm 0.03$ & $1.20^{\mathrm{a}} \pm 0.03$ & & & \\
\hline & Mean & $1.13^{\mathrm{ab}} \pm 0.02$ & $1.18^{\mathrm{a}} \pm 0.02$ & $1.07^{\mathrm{c}} \pm 0.03$ & $1.11^{\mathrm{bc}} \pm 0.04$ & & & & \\
\hline \multirow{4}{*}{$\begin{array}{l}\text { TYMC } \\
(\log \text { CFU/g) }\end{array}$} & 0 & $1.57 \pm 0.06$ & $0.89 \pm 0.01$ & $0.78 \pm 0.05$ & $0.61 \pm 0.04$ & $0.96^{\mathrm{b}} \pm 0.04$ & \multirow{4}{*}{$<.0001$} & \multirow{4}{*}{0.0008} & \multirow{4}{*}{0.4327} \\
\hline & 30 & $1.75 \pm 0.08$ & $1.17 \pm 0.31$ & $0.78 \pm 0.05$ & $0.71 \pm 0.02$ & $1.10^{\mathrm{b}} \pm 0.11$ & & & \\
\hline & 60 & $1.74 \pm 0.04$ & $1.47 \pm 0.09$ & $1.13 \pm 0.08$ & $0.85 \pm 0.05$ & $1.30^{\mathrm{a}} \pm 0.05$ & & & \\
\hline & Mean & $1.68^{\mathrm{a}} \pm 0.06$ & $1.17^{\mathrm{b}} \pm 0.14$ & $0.90^{c} \pm 0.06$ & $0.72^{c} \pm 0.04$ & & & & \\
\hline
\end{tabular}

Mean in each row and column having different superscript varies significantly $(\mathrm{p}<0.05)$.

$\mathrm{T}_{1}$, Control; $\mathrm{T}_{2}, 1.5 \mathrm{KGy}$ irradiated; $\mathrm{T}_{3}, 2 \mathrm{KGy}$ irradiated and $\mathrm{T}_{4}, 4 \mathrm{KGy}$ irradiated.

DI, Days of Intervals; Treat, Treatment and $\mathrm{T} * \mathrm{DI}$, Interaction of Treatment and Days of Intervals.

TVC, total viable count; TCC, total coliforms count and TYMC, total yeast and molds count.

\subsubsection{Total coliform counts $(\log \mathrm{CFU} / \mathrm{g})$}

The coliform bacterial count of $\mathrm{T}_{1}, \mathrm{~T}_{2}, \mathrm{~T}_{3}$ and $\mathrm{T}_{4}$ type irradiated meats are shown in Table 4 and which indicated that coliform bacterial count was very low in $2.0 \mathrm{KGy}$ irradiated meat. Result showed that there was significant difference between control and irradiated meat samples. No significant changes observed in TCC between 0 day and 60 days storage periods but significantly differences were found at 30 day of storage group than others. The present study is in harmony with the findings (Inamura et al., 2012) reported that irradiated samples showed the decrease in microbiological counts of total coliforms and might be safe up to 8 months of storage after gamma irradiation. Mantilla et al. (2010) also tested the effect of irradiation with doses of $3 \mathrm{KGy}$ and a modified atmosphere $(80 \% \mathrm{CO} 2 / 20 \% \mathrm{~N} 2)$ on the growth of coliforms only developed in samples packed in air and in the non-irradiated and non-modified atmosphere.

\subsubsection{Total yeast and mold counts $(\log \mathrm{CFU} / \mathrm{g})$}

Statistically significant differences observed in total yeast and mold counts (TYMC) between non-irradiated and irradiated groups (Table 4). Increased dose of irradiation decreased TYMC in meat samples. With the advancement of storage periods increased trend of TYMC had been observed and Badr (2004) reported that irradiation of rabbit meat significantly reduced the counts of yeasts and molds by 84 and $94 \%$, respectively. Ahmed et al. (2009) also reported that $4 \mathrm{kGy}$ was needed to control the fungal growth of sun-dried fish. It has been stated that yeasts and molds are sensitive to the irradiation process because of their large genomic structure (Fallah et al., 2010).

\section{Conclusions}

In conclusion, irradiation doses of both 1.5 and $2 \mathrm{KGy}$ can be effective to control bacterial spoilage and pathogens in BBG meat, through its effectiveness in extending their refrigeration shelf-life without any significant effect on the chemical characteristics or sensory quality.

\section{Conflict of interest}

None to declare. 


\section{References}

Aftab M, I Rafaqat, F Saleem, B Aftab, R Abdullah, M Iqtedar, A Kaleem, T Iftikhar and S Naz, 2015. Enhancement of shelf life and wholesomeness of goat meat by gamma irradiation treatment. Int. J. Biosci., 7: 177-185.

Ahmed MK, M Hasan, MJ Alam, N Ahsan, MM Islam and MS Akter, 2009. Effect of gamma radiation in combination with low temperature refrigeration on the chemical, microbiological and organoleptic changes in pampus Chinensis. World J. Zool., 4: 9-13.

Al-Bachir M and R Zeinou, 2009. Effect of gamma irradiation on microbial load and quality characteristics of minced camel meat. Meat Sci., 82: 119-124.

Al-Bachir M, 2005. The irradiation of spices, packaging materials and luncheon meat to improve the storage life of the end products. Int. J. Food Sci. Technol., 40: 197-204.

Al-Bachir M, S Farah and Y Othman, 2010. Influence of gamma irradiation and storage on the microbial load, chemical and sensory quality of chicken kabab. The J. Phy. Chem., 79: 900-905.

Ali FH and DA Zahran, 2010. Effect of growth enhancers on quality of chicken meat during cold storage. Adv. J. Food Sci.Techno., 2: 216-219.

AMSA, 1995. Research guidelines for cookery, sensory evaluation, and instrumental tenderness measurements of fresh meat. Chicago III. American Meat Science Association and Nutritional Live Stock and Meat Board.

AOAC, 1995. Official method of analysis of the Association of Official Analytical Chemists.17th edition, Association of Official Analytical Chemists, Washington, DC.

Arannilewa ST, SO Salawa, AA Sorungbe and BB Olasalawu, 2005. Effect of frozen period on the chemical, microbiological and sensory quality of frozen tilapia fish (Sarotherodon galilaleus). African J. Biotech., 4: 852-855.

Aymerich T, PA Picouet and JM Monfort, 2008. Decontamination technologies for meat products. Meat Sci., 78: 114-129.

Badr HM, 2004. Use of irradiation to control foodborne pathogens and extend the refrigerated market life of rabbit meat. Meat Sci., 67: 541-548.

Bakalivanova T, S Grigorova and N Kaloyanov, 2009. Effect of irradiation and packaging on lipid fraction of Bulgarian salami during storage. Rad. Phy. Chem., 78: 273-276.

Batzer O and D Doty, 1955. Radiation sterilization, nature of undesirable odors formed by gamma irradiation of beef. J. Agri. Food Chem., 3: 64-67.

Biswas S, AK Das, R Banerjee and N Sharma, 2007. Effect of electrical stimulation on quality of tender stretched chevon sides. Meat Sci., 75: 332-336.

Brewer MS, 2004. Irradiation effects on meat color: A review. Meat Sci., 68: 1-17.

Chen YJ, GH Zhou, XD Zhu, XL Xu, XY Tang and F Gao, 2007. Effect of low dose gamma irradiation on beef quality and fatty acid composition of beef intramuscular lipid. Meat Sci., 75:423-431.

Chun HH, JY Kim, BD Lee, DJ Yu and KB Song, 2010. Effect of UV-C irradiation on the inactivation of inoculated pathogens and quality of chicken breasts during storage. Food Cont., 21: 276-280.

DLS, 2016. Department of Livestock Services. Livestock statistics. Memeogram. Dhaka, Bangladesh.

Fallah AA, S Saei-Dehkordi, and M Rahnama, 2010. Enhancement of microbial quality and inactivation of pathogenic bacteria by gamma irradiation of readyto- cook Iranian barbecued chicken. Rad. Phy. Chem., 79: 1073-1078.

Ferawati, E Purwati, Arief and Khalil, 2015. Effect of gamma irradiation technology on the microbial quality and sensory attributes of fresh meat in Pondok Labu Traditional Market, South Jakarta. Pak. J. Nutr., 14: 693-697.

Husain SS, MR Amin and ABMM Islam, 1998. Goat production and its breeding strategy in Bangladesh. In: proceedings of First National Workshop on Animal Breeding held in Bangladesh Agricultural University, Mymensingh. pp. 17-36.

Inamura PY, VB Uehara, CAHM Teixeira and NL Mastro, 2012. Mediate gamma radiation effects on some packaged food items. Rad. Phy. Chem., 81: 1144-1146.

Kanatt SR, R Chander and A Sharma, 2007. Antioxidant potential of mint (Mentha spicata L.) in radiation processed lamb meat. Food Chem., 100: 451-458.

Kim IS, C Jo, KH Lee, EJ Lee, DU Ahn and SN Kang, 2012. Effects of low-level gamma irradiation on the characteristics of fermented pork sausage during storage. Rad. Phy. Chem., 81: 466-472.

Konieczny P, J Stangierski and J Kijowski, 2007. Physical and chemical characteristics and acceptability of home style beef jerky. Meat Sci., 76: 253-257. 
Kundu D, G Alexander, L Chenyuan, A Goswami and H Richard, 2013. Use of low dose e-beam irradiation to reduce E. coli O157:H7, non-O157 (VTEC) E. coli and Salmonella viability on meat surfaces. Journal of Food Science, 42: 354-359.

Lee JH, G Kannan, KR Eega, B Kouakou and WR Getz, 2008. Nutritional and quality characteristics of meat from goats and lambs finished under identical dietary regime. Small Rum. Res., 74: 255-259.

Lescano G, P Narvaiz, E Kairiyama and N Kaupert, 1991. Effect of chicken breast irradiation on microbiological, chemical and organoleptic quality. Leb. Wiss. Technol., 24: 130-134.

Lewis SJ, SA Vela, SL Cuppett and SR Mckee, 2002. Effect of electron beam irradiation on poultry meat safety and quality. Poultry Sci., 81: 896-903.

Li X, G Lindahl, G Zamaratskaia and K Lundstrom, 2012. Influence of vacuum skin packaging on color stability of beef longissimus lumborum compared with vacuum and high-oxygen modified atmosphere packaging. Meat Sci., 92: 604-609.

Mancini RA and MC Hunt, 2005. Current research in meat color. Meat Sci., 71: 100-121.

Mantilla SPS, EB Santos, EC Vital, SB Mano, MQ Freitas and RB Franco, 2010. Efeito combinado da embalagem em atmosfera modificada e radiacao gamma na microbiologia e na aceitacao sensorial de files de peito de frango resfriados. Biotemas, 23: 149-155.

Modi VK, PZ Sakhare, NM Sachindra and NS Mahendrakar, 2008. Changes in quality of minced meat from goat due to gamma irradiation. J. Mus. Foods, 19: 430-442.

Morales DA, I Moreno-Indias, A Falcon, A Arguello, D Sanchez-Macias, J Capote and N Castro, 2009. Effects of various packaging systems on the quality characteristic of goat meat. Asian-Aust. J. Anim. Sci., 22: 428432.

Nam KC and DU Ahn, 2002. Carbon monoxide-heme pigment is responsible for the pink color in irradiated raw turkey breast meat. Meat Sci., 60: 25-33.

O'Bryan CA, PG Crandall, SC Ricke and DG Olson, 2008. Impact of irradiation on the safety and quality of poultry and meat products: A review. Crit. Rev. Food Sci. Nutr., 48: 442-457.

Pena F, A Bonvillani, B Freire, M Juarez, J Perea, and G Gomez, 2009. Effects of genotype and slaughter weight on the meat quality of coriollo cordobes and anglonubian kids produced under extensive feeding conditions. Meat Sci., 83: 417-422.

Rukunudin IH, PJ White, CJ Bern and TB Bailey, 1998. A modified method for determining free fatty acids from small soybean oil sample sizes. J. Amer. Oil Chem. Soc., 75: 563-568.

Salahuddin M, T Siddiqua, MN Hasan, MS Rana and MAK Azad, 2017. Status of housing profile and feeding management of Black Bengal Goats in northern districts of Bangladesh. Asian J. Med. Biol. Res., 3: 61-65.

Sallam KI, M Ishioroshi and K Samejima, 2004. Antioxidants and antimicrobial effects of garlic in chicken sausage. Leb.Wiss. Technol., 37: 849-855.

Schmedes A and G Homer, 1989. A new thiobarbituricacid (TBA) method for determining freemalondialdehyde (MDA) and hydroperoxides selectively as a measure of lipidperoxidation. J. Amer. Oil Chem. Soc., 66: 813817.

Sohn SH, A Jang, JK Kim, HP Song, JH Kim, M Lee and C Jo, 2009. Reduction of irradiation off-odor and lipid oxidation in ground beef by gamma-tocopherol addition and the use of a charcoal pack. Rad. Phys. Chem., 78:141-146.

Sultana A, A Nakanishi, BC Roy, W Mizunoya, R Tatsumi, T Ito, S Tabata, H Rashid, S Katayama and Y Ikeuchi, 2008. Quality improvement of frozen and chilled beef biceps femoris with the application of saltbicarbonate solution. Asian-Aust. J. Anim. Sci., 21: 903-911.

Yim DG, C Jo, HC Kim, KS Seo and KC Nam, 2016. Application of electron-beam irradiation combined with aging for improvement of microbiological and physicochemical quality of beef Loin. Korean J. Food Sci. Anim. Res., 36: 215-22.

Zhou GH, XL Xu and Y Liu, 2010. Preservation technologies for fresh meat-a review. Meat Sci., 86: 119-28. 